\title{
Surface water quality at Boete Slimes Dam, AngloGold Ashanti Ltd Obuasi
}

\author{
S. A. Ndur, N. A. Amegbey \\ Department of Mineral Engineering, University of Mines and Technology, PO Box 237, Tarkwa, Ghana
}

Email address:

samndur@gmail.com (S. A. Ndur), namegbey@yahoo.com (N. A. Amegbey)

To cite this article:

S. A. Ndur, N. A. Amegbey. Surface Water Quality at Boete Slimes Dam, AngloGold Ashanti Ltd Obuasi, International Journal of Environmental Monitoring and Analysis. Vol. 1, No. 2, 2013, pp. 53-57. doi: 10.11648/j.ijema.20130102.13

\begin{abstract}
Mining activities around the Boete Slimes Dam (BSD) of AngloGold Ashanti, Obuasi Mine, and its likely impact on surface water quality around the BSD, was investigated. Analyses of samples taken from Pompo stream and Kwabrafo stream and the confluence of the two streams draining the Boete Slimes Dam area showed that Conductivity, Total Suspended Solids (TSS), Total Dissolved Solids (TDS), Sulphate ( $\mathrm{SO}_{4}{ }^{2-}$ ), Cyanide (CN), and Arsenic (As) had values higher than EPA Guideline values, whiles Zinc $(\mathrm{Zn})$, Lead $(\mathrm{Pb})$ and Iron $(\mathrm{Fe})$ were within acceptable range. Comparison of calculated and measured levels of conservative parameters at the confluence of the two streams using the mixing zone model corresponded well with a regression coefficient of between 0.79 and 0.93 . The paper concluded that there is negative impact of the activities at Boete on the quality of Kwabrafo stream. The study also revealed that the company could save at least \$1776 per sampling point annually since sampling at the confluence of the two streams could be suspended.
\end{abstract}

Keywords: Mining, Surface Water, Slimes Dam, Mixing Zone

\section{Introduction}

Over the years, the Pompora Treatment Plant (PTP) at AngloGold Ashanti (AGA), Obuasi employed roasting pre-treatment method to process several million tonnes of sulphide ores from its Sansu pits, and the tailings deposited in 4 slimes dams together called the Boete Slimes Dam (BSD). During the operation of the PTP, Zn dust dose from a Crowe Tower was pumped into the eluent to help in the precipitation of gold in the Johnson Press. This was stopped after the PTP was decommissioned in 2000.

In 2000 before mining operations commenced at Boete Slimes Dam (BSD). The total ore reserve at AGA was 1000000 tonnes at a grade of 2.5 grams per tonne $(\mathrm{g} / \mathrm{t})$. As at June 2006, the remaining reserves were 500000 tonnes of ore. There was the need for AGA to find other sources of ore to maintain gold production, including re-mining of old tailings material.

In 2000, AGA began re-mining the old BSD using the hydraulic mining method, an activity which caused the Kwabrafo stream to be diverted. This caused a hydrological imbalance downstream and introduced $\mathrm{Fe}$, $\mathrm{Zn}, \mathrm{Pb}$, and As into nearby water bodies [1].Close to BSD, the Pompo stream flows east of Slimes Dam 5 and
6 (Fig 1). The Kwabrafo stream flows west of the dam at a distance of $1.84 \mathrm{~km}$ from Diawuoso village. Wonnipaninadue village is located $1.03 \mathrm{~km}$ from Slimes Dam 6. These two villages with a population of 195000 depend mostly on these streams for domestic and commercial purposes [2]. As a result, the mine undertakes routine monitoring of these waters, a venture generally expensive for the mining company. This paper aims at assessing the water quality of the streams around the BSD mining area, and to explore possible avenues to optimise the cost of sampling.

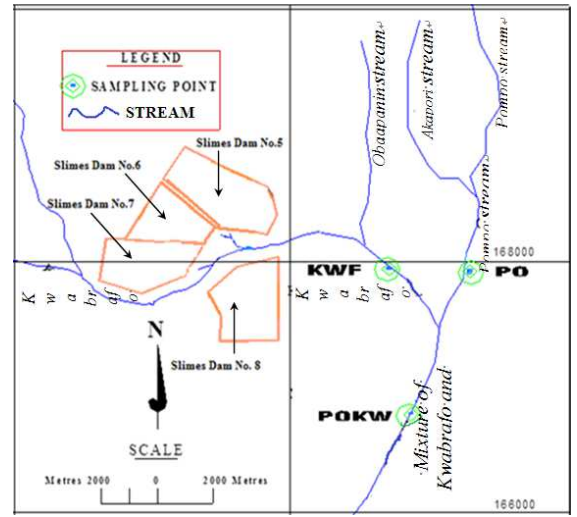

Fig. 1. Sampling Points PO, KWF and POKW at Boete Slimes Dam. 


\subsection{Mining and Processing Activities}

At BSD hydraulic mining is employed to exploit the ore, which consist of old tailings material that originated from the old treatment plant called Pompora Treatment Plant (PTP). Hydraulic mining uses the energy in a fluid to do work and represent a practical application of Bernoulli's equation [3]. Fig 2 shows a monitoring gun in operation at BSD 6. The material (slurry) at a pulp density of $40-45 \%$ from BSD is pumped to the Tailings Treatment Plant (TTP) where there is re-pulping of the slurry from $75 \%$ passing 75 microns to $80-85 \%$ passing 75 microns before gold extraction by the conventional CIL method.

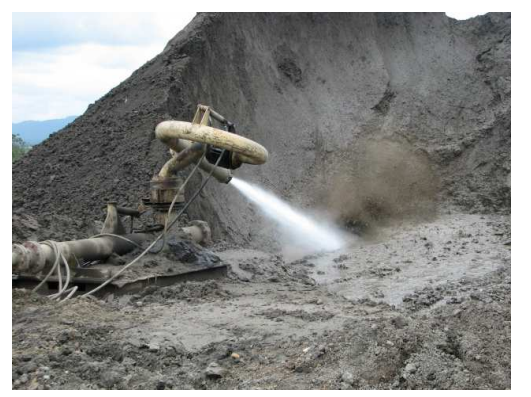

Fig. 2. Monitoring Gun in Operation at Boete Slimes Dam 6.

\subsection{Environmental Impacts of Mining at Boete Slimes Dam}

Environmental issues that could arise from the mining practice at BSD include contamination of water and soil by the release of cyanide, arsenic, sulphates and heavy metals. Other environmental concerns include seepage of contaminated water into ground water and the failure of tailings dam containment (Anon, 2001).

\section{Sampling and Analysis}

Sampling was undertaken at sample points established by the mine following protocols developed by the American Public Health Association [4]. Water sampling data from 14th February 2007 to 4th December 2007 at three sampling points PO, KWF and POKW on Pompo, Kwabrafo and the confluence of Pompo and Kwabrafo streams respectively were obtained. Ten (10) parameters were determined; these are $\mathrm{pH}, \mathrm{EC}, \mathrm{TDS}, \mathrm{TSS}, \mathrm{SO} 4$, Free cyanide $(\mathrm{CN}), \mathrm{Pb}, \mathrm{As}, \mathrm{Fe}$ and $\mathrm{Zn}$. Stream water samples were analysed at AGA Environmental Laboratory using standard procedures. Conductivity and $\mathrm{pH}$ for water samples were determined in the field using a Corning pH/C 107 meter and a Hanna microcomputer conductivity meter respectively. Metals and metalloid concentrations were analysed on a Varian 200 Atomic Absorption Spectrometer (AAS). Field blanks, sample site duplicates and analytical duplicates were analysed for quality control and quality assurance.

\section{The Mixing Zone Model}

The Mixing Zone Model was applied to the six conservative parameters that were sampled. These are TDS, TSS, As, Zn, Pb, and Fe. Accordingly, mass flow equations 1 and 2 were applied to measured conservative parameters over the sampling period to determine the concentration at the downstream after the confluence of the streams.

$$
\begin{gathered}
C_{r}=\frac{C_{w} Q_{w}+C_{u} Q_{u}}{Q_{r}} \\
Q r=Q u+Q w
\end{gathered}
$$

where: $C_{r}=$ concentration in the river downstream, $\mathrm{mg} / \mathrm{L}$

$$
\begin{gathered}
\mathrm{C}_{\mathrm{w}}=\text { concentration in waste discharge, } \mathrm{mg} / \mathrm{L} \\
\mathrm{C}_{\mathrm{u}}=\text { upstream river concentration, } \mathrm{mg} / \mathrm{L} \\
\mathrm{Q}_{\mathrm{u}}=\text { upstream river flow, } \mathrm{m}^{3} / \mathrm{s} \\
\mathrm{Q}_{\mathrm{w}}=\text { waste discharge rate, } \mathrm{m}^{3} / \mathrm{s}
\end{gathered}
$$

The assumptions made during modeling are that: at a certain point downstream the waste discharged will be uniformly mixed across the cross section area of the stream, the material being discharged from the Slimes Dam is a conservative pollutant whose concentration would not change as the stream moves down stream and the stream is shallow and narrow.

\section{Results}

The range of values obtained, at the three sampling points and the EPA Guidelines are shown in Table 1. Comparison of the results of calculated and measured conservative parameters over the sampling period produced a regression coefficient of between $0.79-0.93$. Results of the model as applied to data for $14^{\text {th }}$ February samples are shown in Table 2.

Table 2. Model Results.

\begin{tabular}{lllll}
\hline Parameter & \multicolumn{2}{l}{ Measured Value } & & Model Value \\
\hline & PO & KWF & POKW & POKW \\
\hline TDS (mg/L) & 90.30 & 94.60 & 93.00 & 92.48 \\
TSS (mg/L) & 26.40 & 28.00 & 27.40 & 27.21 \\
Arsenic (mg/L) 0.81 & 1.97 & 1.45 & 1.40 \\
Zinc (mg/L) & 0.06 & 0.08 & 0.07 & 0.07 \\
Lead (mg/L) & 0.09 & 0.10 & 0.09 & 0.10 \\
Iron (mg/L) & 0.31 & 0.02 & 0.15 & 0.16 \\
\hline
\end{tabular}


Table 1. Ranges of Results of Water Analyses at Sample Points PO, KWF, and POKW.

\begin{tabular}{|c|c|c|c|c|}
\hline \multirow{2}{*}{ Parameters Analyzed } & \multicolumn{3}{|c|}{ Sample Locations } & \multirow[t]{2}{*}{ Ghana EPA Guidelines } \\
\hline & PO & KWF & POKW & \\
\hline pH Range & $6.20-7.80$ & $6.50-7.90$ & $6.80-7.60$ & $6.5-8.5$ \\
\hline Conductivity $(\mu \mathrm{S} / \mathrm{cm})$ & $335.09-677.91$ & $1831.94-1872.08$ & $1322.40-1682.04$ & 1500 \\
\hline TDS (mg/L) & $176.55-376.94$ & $749.00-843.88$ & $488.47-661.13$ & 1000 \\
\hline TSS (mg/L) & $27.73-32.00$ & $49.77-63.25$ & $34.93-57.60$ & 50 \\
\hline Sulphate (mg/L) & $669.18-766.94$ & $700.08-723.35$ & $705.33-735.40$ & 250 \\
\hline Free Cyanide (mg/L) & $0.02-0.13$ & $0.03-0.61$ & $0.03-0.09$ & 0.07 \\
\hline Arsenic (mg/L) & $0.25-1.15$ & $1.73-3.62$ & $1.89-2.55$ & 0.01 \\
\hline Zinc (mg/L) & $0.02-0.03$ & $0.03-0.09$ & $0.02-0.06$ & 3.0 \\
\hline Lead $(\mathrm{mg} / \mathrm{L})$ & $0.01-0.05$ & $0.02-0.06$ & $0.05-0.07$ & 0.1 \\
\hline Iron $(\mathrm{mg} / \mathrm{L})$ & $0.25-0.94$ & $0.12-0.53$ & $0.11-0.28$ & 0.1 \\
\hline
\end{tabular}

\section{Discussion}

\subsection{Physico-Chemical Parameters}

From Table 1 it is observed that near-neutral $\mathrm{pH}$ values were obtained at KWF (6.20-7.80) compared to the slightly lower values at PO (6.50-7.90) during the study period. The range of $\mathrm{pH}$ values measured at POKW (6.80-7.60) was between the values measured at KWF and PO. The slightly acidic $\mathrm{pH}$ values at certain points could be due to run-off from the natural soils in the area which are known to be acidic [1],The Kwabrafo stream, which is close to the BSD mining area, recorded the highest $\mathrm{pH}$ value of 7.90. Ores mined at Obuasi contain approximately $1 \%$ sulphides and $2 \%$ carbonates [5].The carbonate content is enough to neutralize acids generated during oxidation of sulphide minerals during storage. In addition lime was added during the gold recovery processes at PTP and these aids in the neutralization process. It is important to note that most of the spill off water from the Slimes Dam is used in-house, that is, it is re-circulated into the Monitoring Gun.

The range of conductivity values measured at $\mathrm{PO}$ was lower than the EPA guidelines of $1500 \mathrm{uS} / \mathrm{cm}$ whereas values measured at KWF are higher. This is because the Kwabrafo stream drains the BSD. Comparison of TSS values (Table 1) shows that TSS of streams (KWF) were comparatively higher and above the EPA Guidelines of 50 $\mathrm{mg} / \mathrm{L}$ This is to be expected.

Relatively high TDS values (749.00-843.88 mg/L) were measured at KWF compared to (176.55-376.94) $\mathrm{mg} / \mathrm{L}$ at PO. At POKW, measured values ranged between 488.47 $661.13 \mathrm{mg} / \mathrm{L}$ for most part of the study period. The high TDS values correspond with high Conductivity values. The Kwabrafo stream is close to the mining area, hence run-off water from the surroundings and the slurry discharges from the mine site flow into the stream causing the high TDS value at KWF. This suggests that mining operations at Boete impacts the KWF stream and hence the POKW.

\subsection{Chemical Parameters}

Sulphate constituted the most dominant anion in solution, with generally high concentrations ranging between $669.46-766.94 \mathrm{mg} / \mathrm{L}$ above EPA Guidelines of $250 \mathrm{mg} / \mathrm{L}$ at all the three sampling points PO, KWF and POKW (Table 1). This is to be expected because, the BSD contained tailings material from sulphide minerals such as pyrite $\left(\mathrm{FeS}_{2}\right)$ and arsenopyrite (FeAsS) that were processed at the PTP. Sulphide oxidation during storage produced $\mathrm{SO}_{4}{ }^{2-}$ according to equation 3 :

$$
\mathrm{F}_{e} \mathrm{~S}_{2}+{ }^{7} / 2 \mathrm{O}_{2}+\mathrm{H}_{2} \mathrm{O} \rightarrow \mathrm{F}_{e^{2+}}+2 \mathrm{H}^{+}+2 \mathrm{SO}_{4}{ }^{2-}(3)
$$

Seepage from the tailings facilities and run-offs from the mining operations at Boete can increaseSO ${ }_{4}^{2-}$ 
concentrations in the Streams.

Free cyanide concentrations at KWF (0.03-0.61) are high compared to $0.02-0.13$ at $\mathrm{PO}$, confirming the fact that mining operations at the BSD likely impacts the Kwabrafo stream. Unlike the other parameters, however, $\mathrm{CN}^{-}$ concentrations at POKW is low. This is to be expected because cyanide is known to degrade with time and distance in an exponential manner [6]. Also high temperatures in Obuasi may increase the rate of cyanide degradation as it travels from KWF to POKW. Fresh water from $\mathrm{PO}$ also dilutes $\mathrm{CN}$ concentration through mixing. This might account for low $\mathrm{CN}$ concentrations at POKW. Therefore $\mathrm{CN}$ pollution at POKW is not an issue to worry downstream communities.

\subsection{Arsenic (As) and Heavy Metals}

It is noted that As values are generally high in the area. From Table 1 As concentrations of 1.72-3.62 mg/L were obtained at KWF compared to $0.25-1.15 \mathrm{mg} / \mathrm{L}$ at PO. At POKW 1.89- $2.55 \mathrm{mg} / \mathrm{L}$ were measured. The Kwabrafo stream takes its source from the Pompora Slimes dam, hence, the high arsenic values could be due to spillage from PTP, which might contain some traces of arsenic. Also during the decommissioning and dismantling of the Arsenic Recovery Plant (ARP) at PTP in 2005, arsenic was not recovered; hence effluents from the ARP plant which may have entered the Kwabrafo stream likely contained Asat high concentrations.

Dissolved $\mathrm{Zn}$ concentration ranged from 0.02 to 0.08 $\mathrm{mg} / \mathrm{L}$, which is less than the EPA Guidelines of $2.0 \mathrm{mg} / \mathrm{L}$ as shown in Table 1. During the operation of the PTP, Zn dust dose from a Crowe Tower was pumped into the eluent to help in the precipitation of gold in the Johnson Press. This was stopped after the PTP was decommissioned in 2000. Zinc was no longer used, hence its low concentration in the Streams.

Mean dissolved $\mathrm{Pb}$ concentrations in most of the samples analysed were lower than the EPA Guidelines of $0.10 \mathrm{mg} / \mathrm{L}$ (Table 1 ). This shows that little $\mathrm{Pb}$ is discharged into the Streams from the mining operations. The highest lead value of $0.07 \mathrm{mg} / \mathrm{L} \mathrm{Pb}$ was measured at POKW. The likely reason is that, Lead Nitrate $\left(\mathrm{PbNO}_{3}\right)$ was used for gold precipitation processes in addition to $\mathrm{Zn}$ dust at PTP and TTP may have introduced the $\mathrm{Pb}$ into the system.

Relatively higher Fe values were measured at PO (0.25$0.94 \mathrm{mg} / \mathrm{L})$ than at KWF $(0.12-0.53 \mathrm{mg} / \mathrm{L})$ and POKW (0.11-0.28) $\mathrm{mg} / \mathrm{L}$ (Table 1). This is to be expected because Fe solubility increases with decreasing $\mathrm{pH}$. The relatively low $\mathrm{pH}$ at $\mathrm{PO}$ may therefore increase Fe solubility. At the near-neutral $\mathrm{pH}$ iron exists as $\mathrm{Fe}(\mathrm{OH})_{3}$. It is possible therefore that the iron released by pyrite $\left(\mathrm{FeS}_{2}\right)$ and arsenopyrite (FeAsS) oxidation is precipitated hence its low concentration. Even though ores conveyed to the processing plants (PTP and TTP) contained Fe in the form of $\mathrm{FeAsS}$ and $\mathrm{FeS}_{2}$ iron compounds formed after roasting to release the gold, likely remained stable.

\subsection{Model Application and the Economic Benefits}

Calculated concentrations of selected conservative parameters are compared with measured ones at POKW to establish a relationship between them. From Table 2, it can be observed that calculated values for TDS, TSS, As, Zn, $\mathrm{Pb}$ and $\mathrm{Fe}$ correlate strongly with measured values. The estimated correlation coefficient $(\mathrm{R})$ ranged between 0.79 and 0.93 . The strong correlation between the calculated and measured values at POKW for the conservative parameters means that the concentration of these parameters at POKW can be predicted using the concentration of such parameters at $\mathrm{PO}$ and KWF. The ramification of this correlation is that there is no need taking samples at POKW since the value for conservative parameters at this point can easily be predicted.

The calculated model values for POKW are approximately the same as the measured values as shown in Table 2.The sampling and analysis of the selected parameters at POKW can be suspended. Samples are taken from POKW Stream at least twice a month, but the calculated model values for POKW can be used to predict the measured values for POKW. If this is done, AGA Ltd, Obuasi Mine, can save $\$ 1776.00$ every year (Table 3) on laboratory analyses alone. Even though the amount saved appears small per sample location there are 10 additional sampling points on the mine which are confluences of streams and the model can be applied to predict the concentrations of the conservative parameters. The total savings on laboratory analyses could then be $\$ 19536$.

Table 3 Analytical Cost of Selected Parameters Analysed at POKW.

\begin{tabular}{llll}
\hline $\begin{array}{l}\text { Parameter } \\
\text { Analysed }\end{array}$ & $\begin{array}{l}\text { Cost per Analyte } \\
\text { (US\$) }\end{array}$ & $\begin{array}{l}\text { Cost per Month } \\
\text { (US\$) }\end{array}$ & $\begin{array}{l}\text { Cost per Year } \\
\text { (US\$) }\end{array}$ \\
\hline TDS & 6 & 12 & 144 \\
TSS & 8 & 16 & 192 \\
$\mathrm{As}$ & 15 & 30 & 360 \\
$\mathrm{Zn}$ & 15 & 30 & 360 \\
$\mathrm{~Pb}$ & 15 & 30 & 360 \\
$\mathrm{Fe}$ & 15 & 30 & 360 \\
$\mathrm{Total}$ & 74 & 148 & 1776 \\
\hline
\end{tabular}

\section{Conclusions}

The following conclusions have been drawn:

Mining activities at the Boete Slimes Dam have negatively impacted on the quality of water in the Kwabrafo stream in terms of effluent discharges

Findings from the simple mixing zone model show that the calculated values at POKW compare favourably with measured values. The model is applicable to TSS Conductivity, TSS, As, $\mathrm{Zn}, \mathrm{Pb}$, and Fe. 
This concept can be applied to other sampling points such as Nyame Bekyere, Dankwa Estates, Bongobri, Nyam, STP, Old Chief, Wumase, Coffer Dam, Kwabrafo at Super Mambo and Tailings Dam 6 which are confluences of Streams on the Mine's concession.

The overall budget and financial cost involved in the routine sampling and analysis by AGA Ltd, conducted at POKW and possibly other similar sampling points can be suspended. The company will save up to US\$19536yearly on analysis alone.

\section{Acknowledgements}

The authors will like to thank Mr Daniel Kwesi Adonu for assisting in data collection for this work.

\section{References:}

[1] A. Amanor, and W.A. Gyapong, (2000), 'Geology of
Ashanti GoldfieldsCompany, Obuasi, Unpublished Report, pp. $1-24$

[2] G. Foli, "Physico-Chemical Evaluation of some Mining Impacted Water Bodies within Obuasi Environment", MPhil Project Report, University of Ghana Legon, Accra , pp. 27 69.(2004),

[3] L. H, Hartman,S. G. Britton, D.W Gentry,MKarmis, J. M, Mutmansky, W. J.Schlitt, M. M.Singh, (SME)"Mining Engineering" 2nd Edition Volume 2,(1996)pp.1467 - 1470.

[4] Anon, "Homase Project Environmental Impact Statement", Environmental Department Report of Ashanti Goldfields Company2001,

[5] S. Osae, K. Kase, and M. Yamamoto,Ore Mineralogy and Mineral Chemistry of the Ashanti Gold Deposit at Obuasi, Ghana. Resource Geology, 1999.49(1): p. 1-11.

[6] L Shehong, Z Baoshan, Z.Jianming, and Y.Xiaoying, "The distribution and natural degradation of cyanide in goldmine tailings and polluted soil in arid and semiarid areas". Environmental Geology, 2005a 47(8):1150-1154. 